und Schwellen von Duftgemischen beim Menschen. Leipzig: Johann Ambrosius Barth, 1967.

JOHNSTON, J. W. Quantification of olfactory stimuli. In C. C. Brown (Ed.), Methods in psychophysiology. Baltimore: Williams \& Wilkins, 1967. Pp. 192-220.

KOSTER, E. P. Gewijzigde en geautomatiseerde olfactometer. TNO Nieuws, 1965, 10, $730-734$.

STONE, H. Behavioral aspects of absolute and differential olfactory sensitivity. Annals of the New York Academy of Sciences, 1964, 116 527-534.

ZWAARDEMAKER, H. Olfaktometrie. Fortschr. Med., 1889, 19, 721-731.

\section{NOTES}

1. The authors are indebted to $R$. $M$. Pangborn, PhD, and M. H. Woskow, PhD, University of California, Davis, California, for many suggestions in the preparation of the manuscript.

2. Specifications of technical equipment (flowmeters, valves, etc.) and of capillaries are given in a technical report that is available on request.

3. This experimental work was generously assisted by two coworkers of Dr. W. Franke, Professor for Organic Chemistry at the Technische Hochschule Darmstadt, H. Hennig and Dr. H. Pohl.

\title{
The production and fading of entoptic images
}

ROBERT J. HALL, HUMAN FACTORS RESEARCH, INC., Goleta, California 93017, ROBERT KARSH, U.S. ARMY HUMAN EN GINEERING LABORATORIES, Aberdeen Proving Ground, Maryland 21005, and WILLIAM E. WILSONCROFT, SAN FERNANDO VALLEY STATE COLLEGE, Northridge, Califormia 91324

A new apparatus, suitable for obtaining reliable reports of entoptic images, was developed. Basically, this apparatus moved a small light across the $S$ 's eyelid (transcleral illumination). While the light was moving, Ss reported the appearance of the three entoptic phenomena of interest-retinal blood vessels, foveal images, and background illumination. After initial training with this apparatus, 12 Ss were tested for the differential disappearance (fading) of the entoptic images after the light source stopped moving but continued its transcleral illumination of the retina. Results indicated that although the background image did fade to a dark field, this background fade time $(\bar{X}=1.3 \mathrm{sec})$ is faster than that reported for extemally stabilized images, which may take 2 to $4 \mathrm{sec}$ to fade, and was significantly slower than the very rapid fade times for blood vessels and foveal images. Furthermore, there was no reappearance of these entoptic images.

Entoptic images, or images within the eye, include a variety of phenomena including floaters, afterimages, phosphenes, Haidinger's "Brushes," retinal blood vessels, and foveal images. Some of these (floaters, afterimages, and phosphenes) are quite common everyday occurrences; the others requine specific manipulation in order to be experienced. Looking through a polarized filter at a field of blue light produces Haidinger's "Brushes" (see Ratliff, 1958), and illuminating the retinae through the sclera (eyelid) with a moving light source allows the perception of the retinal blood vessels and foveal images.

Helmholtz (1866) gives an extensive discussion of Purkinje's methods for observing the shadows of retinal blood vessels; in a sense, Purkinje anticipated the results of contemporary work on stabilized images by noting that movement was required to make the retinal blood vessels visible. Normally, retinal blood vessels are true stabilized images; they occur entoptically and are not subject to the types of artifacts, such as slippage of contact lenses (Barlow, 1963), associated with external, optically stabilized images.

The fading of these external images, when the image is cast by a mechanism mounted on a contact lens, has been reported by many investigators (Riggs et al, 1953; Pritchard et al, 1960; Barlow, 1963; and Heckenmueller, 1965). A typical image would consist of a patch of light (about $5 \mathrm{deg}$ of visual angle), with an image (about $2 \mathrm{deg}$ of visual angle) focused at apparent infinity. After a few seconds the image fades and shortly thereafter the field is completely lost. The image may reappear after a short period and then fade again (Pritchard et al, 1960). The complexity of the image (i.e., single line vs human face) determines, in part, its persistence. The more complex images tend to last longer.

A few brief reports (Campbell \& Robson, 1961; Cornsweet \& Dwelley, 1962) have suggested the use of entoptic images to study image stabilization but no data were presented.

The present study explores the use of such entoptic phenomena to study the effects of image stabilization. With the development of the techniques to be described, it has been feasible to overcome the objections that entoptic phenomena may not be compared to the fading of externally stabilized images on the retinae.

\section{METHOD}

The apparatus consisted of three basic parts: a vise-mounted head stabilization mechanism (a dental "bite bar" made of mouth plates covered with dental wax), a scaffolding for placing the transcleral illuminant (bulb, GE No. 22.5) against the S's upper eyelid, and a spring-operated motor system for moving the bulb horizontally between two rails across the S's eyelid.

The 12 Ss were given preliminary training on the apparatus. All Ss were able to report the orientation and color of the retinal blood vessels, the foveal image, and the general background illumination when the transcleral illuminant was moving.

In this experiment, $S$ s were provided with a button, which, when depressed, stopped the motion of the transcieral illuminant across the eyelid. Ss continued to depress the button until the entoptic phenomenon being studied disappeared. A timer recorded the fade time of the entoptic phenomena in milliseconds. The Ss were tested with both eyes; the selection of right or left was randomized. Once an eye was selected, however, observations on all three entoptic images (retinal blood vessels, foveal images, background) were completed for that eye. The order in which a particular entoptic phenomenon was observed was then randomized and each phenomenon was observed for a series of 10 consecutive trials. This procedure was adopted to minimize the difficulties of realignment and adjusting the apparatus.

The Ss were preadapted to normal ambient lighting (approximately $45 \mathrm{~mL}$ ) and, after they were seated and aligned with the apparatus, the unused eye was covered with an eyepatch. All Ss were required to bite the dental impression attached to the scaffolding to ensure head immobilization. The transcleral light was then turned on, and motion across the eyelid began. Ss stopped the motion by depressing a hand-held button and released this button when the entoptic phenomenon had completely faded. At the end of each trial, the transcleral light was turned off. Following each block of 10 
trials, there was a rest period of approximately $5 \mathrm{~min}$.

\section{RESULTS}

Differences between the eyes and between Ss were not statistically significant, although the difference between fade times (durations) for the various entoptic phenomena was reliable $(\mathrm{F}=7.90, \mathrm{df}=2 / 45, \mathrm{p}<.01)$. Multiple comparison tests between these means showed that the background fade time was significantly longer $(\overline{\mathrm{X}}=1.30 \mathrm{sec})$ than that of the retinal blood vessels $(\bar{X}=.99 \mathrm{sec})$ and foveal image $(\bar{X}=.91 \mathrm{sec})$. The latter two means did not differ from each other.

\section{DISCUSSION}

In this study, the entoptic images faded rapidly when the movement of the transcleral light was stopped. The fact that these images disappeared within about $1 \mathrm{sec}$ suggests that they fade faster than externally stabilized images. If one could account adequately for the Ss' response time and the inertia of the mechanical system employed in the present study, the fade times for the entoptic images might be even faster.
It should also be noted that the entoptic images did not reappear after fading, although this is a common occurrence with externally stabilized images. The rapid fade times plus the lack of reappearance suggest that these entoptic images are indeed better "stabilized images" than those produced by external optical stabilization methods. It might also be suggested that the brightness of the entoptic images tends to be closer to the eye's adaptation level (lower contrast) than are external images; this would, of course, facilitate their disappearance.

Perhaps one of the most significant results of this experiment was that the orange background against which the retinal blood vessels were perceived faded and turned dark once the movement of the transcleral source stopped. In many instances when the movement stopped the naive Ss thought that the transcleral source had been turned off. This fading and darkening of the central field of vision indicates that changes, whether they are induced by involuntary eye movement or by the transcleral source, are essential to the basic visual process, namely, the perception of light.

\section{REFERENCES}

BARLOW, H. B. Slippage of contact lenses and other artifacts in relation to fading and regeneration of supposedly stable retinal images. Quarterly Journal of Experimental Psychology, 1963, 15, 36-51.

CAMPBELL, F. W., \& ROBSON, J. G. A fresh approach to stabilized retinal images. Journal of Physiology, 1961, 158, 12.

CORNSWEET, T. N., \& DWELLEY, D. Perfectly stabilized retinal images. Journal of the Optical Society of America, 1962, 52, 598.

DITCHBURN, R., \& FENDER, D. H. The stabilized retinal image. Optica Acta, 1955, 2, 128-133.

HECKENMUELLER, E. G. Stabilization of the retinal image: A review of method, effects and theory. Psychological Bulletin, 1965, 63, 157-169.

HELMHOLTZ, H. L. F. von. Physiological optics (1866 translation). Vol. 1. New York: Dover Publications, 1962.

PRITCHARD, R. M. A., HERON, W., \& HEBB, D. O. Visual perception approached by the method of stabilized images. Canadian Journal of Psychology, 14, 67-77.

RATLIFF, F. Stationary retinal image requiring no attachment to the eye. Journal of the Optical Society of America, 1958, 48, 274-275.

RIGGS, L. A., RATLIFF, F., CORNSWEET, J. C., \& CORNSWEET, T. N. The disppearance of steadily fixated visual test objects. Journal of the Optical Society of America, 1953, 43, 495-501.

WEST, D. C. Flicker and the stabilized retinal image. Vision Research, 1968, 8, 719-745. 